\title{
1 Is it possible to keep the exoskeleton of the crab Callinectes 2 ornatus soft for several days?
}

3 Short Title: Effects of water quality on the molt of crab

4 Diogo Barbalho Hungria1, Ubiratã de Assis Teixeira da Silva² ${ }^{2}$ Leandro Ângelo Pereira ${ }^{3}$,

5 Ariana Cella-Ribeiro ${ }^{4}$ and Antonio Ostrensky ${ }^{2}$

6 'Postgraduate Program in Animal Science, Federal University of Paraná, Curitiba - PR.

7 '2Integrated Group of Aquaculture and Environmental Studies, Federal University of Paraná,

8 Curitiba - PR.

9 '3Federal Institute of Paraná, Paranaguá - PR.

10 4Postdoctoral researcher, Federal University of Rondônia, Porto Velho - RO

11 Corresponding author: Diogo Barbalho Hungria, Paraná avenue, 111, apt. 1101 - Cabral,

12 Curitiba - PR, Brazil ZIP 80035-130. E-mail: bhungria@gmail.com

13 Key words: Soft-shell; Moult; Arthropods; Calcium; Acidification; Ammonification 


\section{Abstract}

15 Soft-shell crab is considered a gastronomic delicacy, reaching high values in the 16 international market. The process of hardening of the crab's exoskeleton after 17 moulting takes approximately two days to complete; however, the duration for which 18 the shell remains at the consistency of high commercial value is only 3 hours on average. After this period, the shell assumes a consistency classified as "paper", 20 later becoming "hard" again. The goal of this work was to evaluate the use of the 21 crabs themselves to alter the chemical characteristics of the water and thereby increase the amount of time during which they can be marketed as "soft-shell crab". In this work, 241 individuals of Callinectes ornatus were used in two experiments. In the first experiment, the animals were maintained in a collective system with filtration and partial daily water renewal. In the second experiment, the crabs were maintained in a collective system with filtration but no water renewal. In Experiment 1, the chemical characteristics of the water remained unchanged over time $(p>0.05)$, and the median time to hardening of the exoskeleton to the paper consistency after moulting was 3 hours. Over the course of Experiment 2, there was a significant reduction $(\mathrm{p}<0.05)$ in $\mathrm{pH}$ and significant increases in the ammonia and nitrite

31 concentrations. When moulting occurred in water with a $\mathrm{pH}$ below 7.3 and total ammonia concentrations above $6.0 \mathrm{mg} / \mathrm{L}$, the crabs' shells did not harden, and it was possible to keep them soft for up to 5 days.

\section{Introduction}

Callinectes ornatus Ordway, 1863 (Crustacea, Decapoda, Portunidae) is a swimmer crab found from North Carolina (USA) to the Rio Grande do Sul (Brazil). It

37 occurs in areas with sand, mud or shell bottoms and inhabits estuarine to marine 
areas at a depth of approximately $75 \mathrm{~m}$ (Carvalho and Couto, 2011; Melo-Filho,

39 1996).

Similar to other arthropods, C. ornatus grows through a process of periodic exoskeleton changes; each shedding of the exoskeleton is known as ecdysis or moult (Drach, 1939; Freeman and Perry, 1985; Newcombe et al., 1949). Immediately after shedding its exoskeleton, the crab presents a soft and flexible integument that has a low level of calcification. In this phase, the animals can be commercialised and consumed whole as "soft-shell crab", a delicacy that is appreciated worldwide and that reaches high market values (Gaudé and Anderson, 2011; Oesterling, 1995; Perry et al., 2010). According to FAO (2013), the annual revenue generated from the production and marketing of soft-shell crab in 2012 was more than US\$ 940 million.

Immediately after moult, $\mathrm{CaCO}_{3}$ deposition begins on the protein matrix of the new exoskeleton. This process involves a complex system of absorption of $\mathrm{Ca}^{2+}$, $\mathrm{CO}_{2}$, and $\mathrm{HCO}_{3}{ }^{-}$and the synthesis of $\mathrm{CaCO}_{3}$ and other elements (Greenaway, 1985; Perry et al., 2001; Wheatly, 1999; Zanotto and Wheatly, 2002). The initially fragile exoskeleton undergoes rapid hardening, providing rigidity and mechanical protection for the animal. Under natural conditions, the hardening of the exoskeleton takes about two days to complete (Cameron and Wood, 1985). During the hardening process, the exoskeleton can be classified into four sequential levels of consistency: soft, leather, paper and hard (Freeman et al., 1987). Only the first two are valued in the international market of soft-shell crabs (Gaudé and Anderson, 2011; Oesterling, 1995; Perry et al., 2010). However, the combined duration of the soft and leathery stages is very short in nature, rarely lasting more than $3 \mathrm{~h}$ (Cameron and Wood, 1985), which obliges commercial producers to inspect all of the animals stocked in 
62 the pre-moulting phase every $4 \mathrm{~h}$ on average (Oesterling, 1995). Extending the

63 duration in which the crab shells remain at the consistencies of high market value

64 would significantly reduce production costs (Perry et al., 2001). Furthermore, it would

65 minimise the damage caused by rapid exoskeleton hardening, providing better

66 quality and uniformity regarding the softness of the product.

67 The goal of this work was to test the viability of using the crab C. ornatus to alter the 68 chemical characteristics of the water to extend the time during which the animals 69 could be marketed as soft-shell crab.

\section{Material and Methods}

\section{Crab collection and maintenance}

Specimens of $C$. ornatus were obtained via trawling by professional fishers at

73 the balneary of Shangri-la, municipality of Pontal do Paraná $\left(25^{\circ} 37^{\prime} \mathrm{S} / 48^{\circ} 25^{\prime} \mathrm{O}\right)$,

74 Paraná, Brazil. Shrimp trawls $12 \mathrm{~m}$ in length and with $20 \mathrm{~mm}$ mesh were used. In each sampling campaign, on average, three trawls of approximately 50 min each were made. Immediately after crab collection from the net, the crabs were separated and transferred to two $70 \mathrm{~L}$ polyethylene tanks with lids, each containing $20 \mathrm{~L}$ of seawater. The tanks received continuous aeration supplied via an $18 \mathrm{~W}$ air compressor. Inside each tank were plastic screens with $2 \mathrm{~mm}$ mesh positioned to reduce contact and prevent fights between the animals and minimise injuries and

81 deaths. Thereafter, $100 \%$ of the water was renewed every half hour during the campaign.

Immediately after capture, the animals were transported to the Marine

84 Aquaculture and Restocking Center (CAMAR) of the Integrated Group of Aquaculture 
The second experiment tested the influence of the non-renewal of water on

and Environmental Studies (GIA), Federal University of Paraná (UFPR), at Pontal do Paraná $\left(25^{\circ} 41^{\prime} 29.94 " \mathrm{~S}, 4^{\circ} 27^{\prime} 57.09 " \mathrm{~W}\right)$. The time elapsed between animal capture and arrival at the laboratory was consistently less than $4 \mathrm{~h}$. Animals that were not used were returned to the sea.

In the laboratory, the crabs were maintained in 1,000 L tanks containing $100 \mathrm{~L}$ of seawater (30 psu) supplied with constant aeration for approximately $6 \mathrm{~h}$. This period was purposely short since a large proportion of the captured individuals were very close to moult. Dead animals were discarded, and the live animals were classified by sex. Then, the crabs were inspected to determine the phase of the moulting cycle. Those individuals at the pre-ecdysis phase were selected for the experiments based on macroscopic indicators (visualisation of an inner line along the edges of the fifth pair of pleopods) (Drach, 1939; Drach and Tchernigovtzeff, 1967; Wehrtmann and Mena-Castañeda, 2003). The selected individuals were weighed on an analytical balance (Marte AL 500c, Brazil; accuracy of $0.01 \mathrm{~g}$ ) and measured (width of the carapace, measured as the distance between the base of the largest lateral spines) with a pachymeter.

\section{Pilot experiments}

Two pilot experiments were carried out. The first experiment tested the influence of fasting on animal survival under laboratory conditions. The animals only began to die after 50 days without access to food. Based on this result and to potential feeding effects on water quality or the process of moult and hardening, the crabs were not fed during the 12 days of each of the main experiments. 
109 significantly higher under water non-renewal than under the periodic renewal of

110 water. In addition, a higher frequency of moult was observed at night (between 18:00

111 and 06:00); this information informed the design of the experimental methodology

112 described below.

\section{Experimental Design}

114 In both experiments, the saltwater had been previously chlorinated and 115 maintained under constant aeration for $24 \mathrm{~h}$. After this period, residual chlorine was 116 neutralised (with $50 \%$ sodium thiosulfate), and the water was stored in the dark in $11725,000 \mathrm{~L}$ tanks. Before use in the experiments, the water was passed through 118 mechanical filters of 5 and $25 \mu \mathrm{m}$ mesh and a UV filter for disinfection. Two 119 experiments were performed and are represented schematically in Figure 1.

120 Experiment 1: Crab maintenance in a collective system with filtration 121 and partial daily water renewal

Sixty-six $C$. ornatus crabs were individually placed in perforated pet bottles

$123(600 \mathrm{~mL})$ and distributed in a system consisting of 20 polyethylene tanks $(71.0 \times 35.5$ $124 \times 35.0 \mathrm{~cm}$, containing $25 \mathrm{~L}$ of seawater each). The tanks were interconnected via a skimmer and a mechanical/biological filter system and were under constant aeration, continuous water recirculation and controlled photoperiod (14L:10D).

The animals were separated into two groups: A1, pre-ecdysis animals $(\mathrm{n}=$

128 46), and AC, control animals (at the inter-ecdysis stage) ( $n=20)$. Each day 129 throughout the experimental period (12 days), 1/3 of the total water volume of the 130 system (333 L) was added, promoting mixing with the water already present, and an 
131 approximately equivalent amount was removed, keeping the total water volume in the

132 system constant.

133 Experiment 2: Crab maintenance in a collective system with filtration and without water renewal

One hundred and seventy-six $C$. ornatus crabs were individually placed in perforated $(600 \mathrm{~mL})$ pet bottles and distributed among 12 polyethylene tanks $(71.0 \mathrm{x}$

$13735.5 \times 35.0 \mathrm{~cm}$, containing approximately $30 \mathrm{~L}$ of water each). Each tank contained a 138 protein skimmer and a mechanical/biological filter and was subjected to constant 139 aeration, continuous water recirculation and controlled photoperiod (14L:10D).

141 B2, pre-ecdysis animals $(n=40)$; and BC, control inter-ecdysis animals $(n=52)$. In 142 addition, three tanks containing water only were maintained throughout the 143 experimental period (12 days) for comparison of physical and chemical water 144 variables between these tanks and the 3 treatment groups. There was no water 145 renewal during the experiment. 


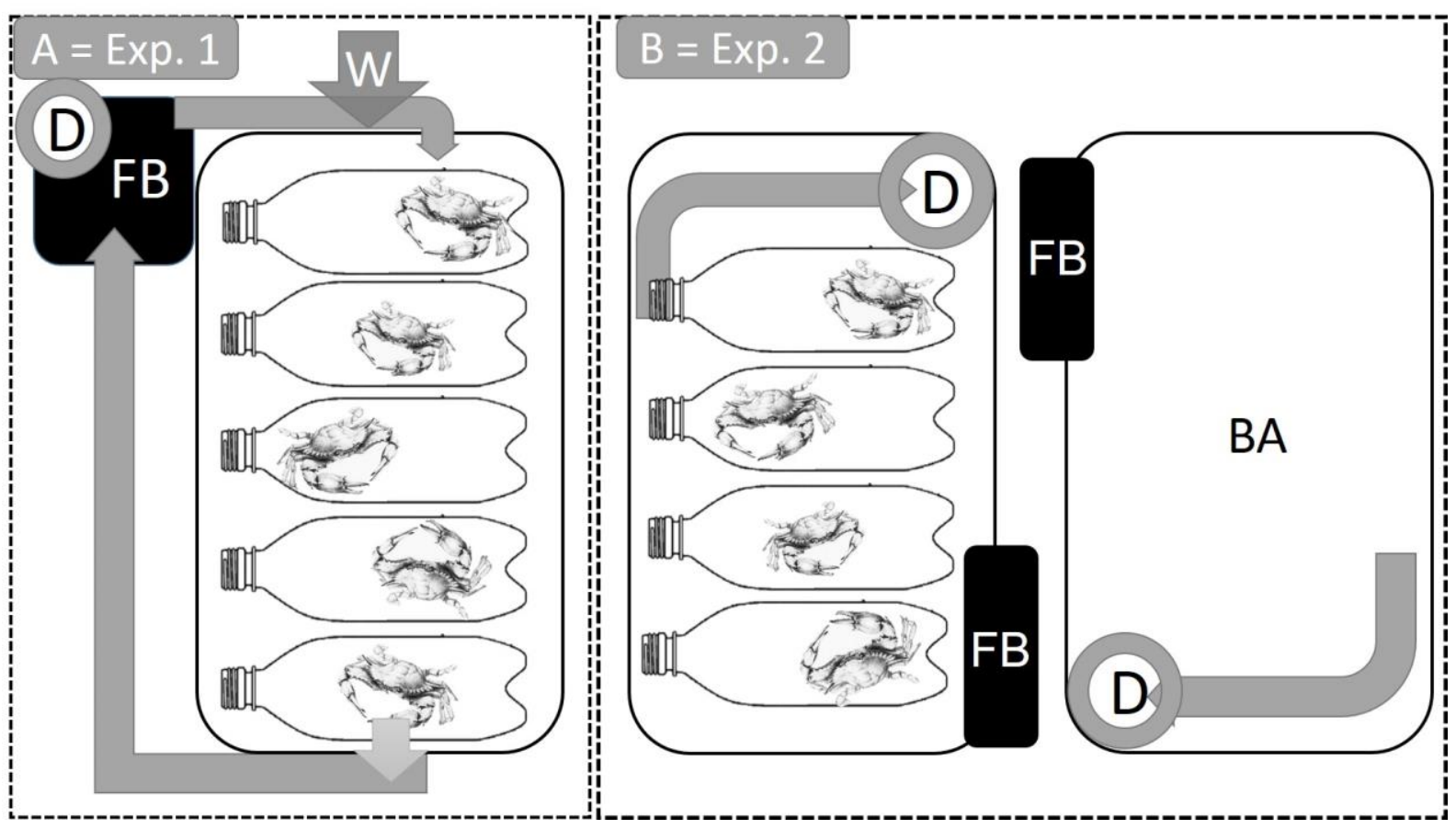

149 Figure 1. Schematic representations of the experimental systems. A: Experiment 1 (Exp. 1): 66 crabs 150 (46 in pre-ecdysis stage and 20 in inter-ecdysis stage) maintained in a collective system with filtration and partial daily water renewal. B: Experiment 2 (Exp. 2): 175 crabs (123 in pre-ecdysis stage and 52 in inter-ecdysis stage) maintained in a collective system with filtration but without water renewal. $A=$ external water supply; $\mathrm{D}=$ protein skimmer; $\mathrm{FB}=$ mechanical $/$ biological filter; $\mathrm{BA}=$ Water control.

Table 1. Summary of the general conditions of the experiments performed to evaluate the effects of water quality on the hardening time of the exoskeleton in Callinectes ornatus and width and weight data of the animals (mean $\pm S D$ ). NA: not applicable.

\begin{tabular}{|c|c|c|c|c|c|c|c|c|}
\hline Experiment & Group & Experimental Unit & Stage & $\mathrm{N}$ & $\begin{array}{l}\text { Width } \\
(\mathrm{mm}) \\
( \pm \mathrm{sd})\end{array}$ & $\begin{array}{l}\text { Weight } \\
\text { (g) ( } \pm s d)\end{array}$ & $\begin{array}{c}\text { Water } \\
\text { Volume } \\
(\mathrm{L})\end{array}$ & $\begin{array}{c}\text { Water } \\
\text { Sampling } \\
\text { Frequency }\end{array}$ \\
\hline \multirow{2}{*}{1} & $\mathrm{~A} 1$ & Tank & $\begin{array}{c}\text { Pre- } \\
\text { ecdysis }\end{array}$ & 46 & $\begin{array}{c}45.4 \\
( \pm 6.16)\end{array}$ & $\begin{array}{c}15.04 \\
( \pm 6.11)\end{array}$ & 0.6 & $24 \mathrm{~h}$ \\
\hline & $A C$ & Tank & $\begin{array}{l}\text { Inter- } \\
\text { ecdysis }\end{array}$ & 20 & $\begin{array}{c}61.55 \\
( \pm 10.53)\end{array}$ & $\begin{array}{c}35.57 \\
( \pm 16.9)\end{array}$ & 0.6 & $24 \mathrm{~h}$ \\
\hline \multirow{8}{*}{2} & \multirow{3}{*}{ B1 } & $\begin{array}{c}\text { Tank (Replicate } \\
\text { 1) }\end{array}$ & \multirow{3}{*}{$\begin{array}{l}\text { Pre- } \\
\text { ecdysis }\end{array}$} & 27 & $\begin{array}{c}50.7 \\
( \pm 7.78) \\
\end{array}$ & $\begin{array}{c}16.64 \\
( \pm 7.03)\end{array}$ & 32.5 & $12 \mathrm{~h}$ \\
\hline & & $\begin{array}{c}\text { Tank (Replicate } \\
\text { 2) }\end{array}$ & & 27 & $\begin{array}{c}3.10 \\
( \pm 7.36)\end{array}$ & $\begin{array}{c}14.36 \\
( \pm 7.47)\end{array}$ & 32.5 & $12 \mathrm{~h}$ \\
\hline & & $\begin{array}{l}\text { Tank (Replicate } \\
\text { 3) }\end{array}$ & & 29 & $\begin{array}{c}47.5 \\
( \pm 5.12)\end{array}$ & $\begin{array}{c}15.11 \\
( \pm 4.92)\end{array}$ & 32.5 & $12 \mathrm{~h}$ \\
\hline & \multirow{3}{*}{ B2 } & $\begin{array}{c}\text { Tank (Replicate } \\
\text { 1) }\end{array}$ & \multirow{3}{*}{$\begin{array}{l}\text { Pre- } \\
\text { ecdysis }\end{array}$} & 14 & $\begin{array}{c}48.1 \\
( \pm 8.25)\end{array}$ & $\begin{array}{c}16.46 \\
( \pm 8.08)\end{array}$ & 30 & $12 \mathrm{~h}$ \\
\hline & & $\begin{array}{c}\text { Tank (Replicate } \\
\text { 2) }\end{array}$ & & 13 & $\begin{array}{c}46.4 \\
( \pm 7.02)\end{array}$ & $\begin{array}{l}15.40 \\
( \pm 6.7)\end{array}$ & 30 & $12 \mathrm{~h}$ \\
\hline & & $\begin{array}{c}\text { Tank (Replicate } \\
\text { 3) }\end{array}$ & & 13 & $\begin{array}{c}47.0 \\
( \pm 6.64)\end{array}$ & $\begin{array}{l}14.75 \\
( \pm 6.3)\end{array}$ & 30 & $12 \mathrm{~h}$ \\
\hline & \multirow[t]{2}{*}{$\mathrm{BC}$} & $\begin{array}{l}\text { Tank (Replicate } \\
\text { 1) }\end{array}$ & \multirow{2}{*}{$\begin{array}{l}\text { Inter- } \\
\text { ecdysis }\end{array}$} & 17 & $\begin{array}{c}56.2 \\
( \pm 2.9)\end{array}$ & $\begin{array}{c}26.51 \\
( \pm 5.07)\end{array}$ & 32.5 & $12 \mathrm{~h}$ \\
\hline & & Tank (Replicate & & 17 & 59.7 & 28.31 & 32.5 & $12 \mathrm{~h}$ \\
\hline
\end{tabular}




\begin{tabular}{|c|c|c|c|c|c|c|c|c|}
\hline Experiment & Group & Experimental Unit & Stage & $\mathrm{N}$ & $\begin{array}{l}\text { Width } \\
(\mathrm{mm}) \\
( \pm \mathrm{sd})\end{array}$ & $\begin{array}{l}\text { Weight } \\
\text { (g) ( }( \pm \mathrm{sd})\end{array}$ & $\begin{array}{l}\text { Water } \\
\text { Volume } \\
(\mathrm{L})\end{array}$ & $\begin{array}{l}\text { Water } \\
\text { Sampling } \\
\text { Frequency }\end{array}$ \\
\hline & & $2)$ & & & $( \pm 3.8)$ & $( \pm 6.1)$ & & \\
\hline & & $\begin{array}{c}\text { Tank (Replicate } \\
3)\end{array}$ & & 18 & $\begin{array}{r}56.65 \\
( \pm 4.93)\end{array}$ & $\begin{array}{c}26.54 \\
( \pm 7.95)\end{array}$ & 32.5 & $12 \mathrm{~h}$ \\
\hline & BA & $\begin{array}{c}\text { Tank } \\
\text { (3 Replicates) }\end{array}$ & NA & NA & NA & NA & 32.5 & $12 \mathrm{~h}$ \\
\hline
\end{tabular}

160 Experimental Procedures

162 first four days, every six hours on the following five days, and every 12 hours on the

163 last three days of experimentation, preferably between 18:00 and 06:00 h. These

164 times were selected based on the results of the pilot experiments. removing any moulted exoskeletons (to prevent the animals from obtaining calcium

167 by feeding on them), evaluating the consistency of the carapace of those animals 168 that had moulted, and removing any dead animals. Evaluating the consistency of the exoskeleton was performed by pressing the carapace with an index finger. Sufficient 170 pressure was applied to deform the carapace but not injure the animal or break the 171 carapace when rigid. Based on the resistance to pressure and texture of the 172 exoskeleton, its consistency (Co) was classified by the evaluator as follows: hard 173 before ecdysis (1), soft (2), leather (3), soft paper (4), hard (5) or hard paper - after 174 ecdysis (6). To reduce and standardise the error, a single evaluator performed the 175 consistency assessments in both experiments.

\section{Water analysis}


180 all experimental units. Water samples were collected from the units, labelled and

181 immediately frozen $\left(-20^{\circ} \mathrm{C}\right)$ for later evaluation of the physical and chemical

182 variables. For group A1, water collection was performed every 24 hours before the 183 new water was added to the system. For groups B1, B2, BC and BA, $50 \mathrm{~mL}$ of water 184 was collected every $12 \mathrm{~h}$.

At the end of the experiments, the frozen water samples were analysed with respect to the following parameters: $\mathrm{Na}^{+}, \mathrm{K}^{+}, \mathrm{Ca}^{2+}$ and $\mathrm{NO}_{3}$ (electrodes of the 187 LAQUAtwin series, Horiba Scientific $\AA$, Japan) and total ammonia $\left(\mathrm{NH}_{3}+\mathrm{NH}_{4}{ }^{+}\right)$and $188 \mathrm{NO}_{2}^{-}$(SpectraMax® $\mathrm{m} 2$ spectrophotometer, USA). Measurements were performed following APHA (2005) and Büldt and Karst (1999). The determinations of $\mathrm{Mg}_{2}{ }^{+}$and

$190 \mathrm{Cl}^{-}$were performed using colourimetry (Labtest ${ }^{\circledR}$, Brazil) at a wavelength of $540 \mathrm{~nm}$ 191 and $470 \mathrm{~nm}$, respectively (SpectraMax® $\mathrm{m} 2$, USA), according to the method 192 described by Clarke (1950).

\section{Statistical analyses}

The survival of the animals during the experiments was analysed through

Kaplan-Meier curves. The data were grouped by treatment (groups), and the

197 Where the normality hypothesis was rejected, non-parametric Mann-Whitney or 198 Kruskal-Wallis tests were used.

Multiple linear regression analysis was performed to model the influences of 200 the physical and chemical variables that determine water quality on exoskeleton 201 hardening time. The assumption of the independence of the physical and chemical 202 variables was upheld, the hypothesis of autocorrelation and collinearity (using 
203 Durbin-Watson and the serial error correlation tests) was rejected, and the normality 204 of the error was confirmed.

To limit the number of variables and thereby minimise the complexity of the

models without a significant loss of the information offered by the total set of original

207 variables, we select only those variables that: 1) were statistically significant ( $p<$ $2080,05)$ and; 2) contributed more than $5 \%$ to the coefficient of determination $\left(R^{2}\right)$ of the 209 model or that caused the $\mathrm{R}^{2}$ value to move into a higher category when it was 210 included in the model, following the classification proposed by Mukaka (2012): very 211 weak:: $\mathrm{R}^{2}<0,19$; weak: $0,20>\mathrm{R}^{2}<0,39$; moderate: $0,40>\mathrm{R}^{2}<0,69$; strong: $0,70>$ $212 R^{2}<0,89$; very strong: $R^{2}>0,90$.

\section{Results}

\section{Ecdysis}

Significant effects of sex on survival rate, ecdysis, or exoskeleton post-ecdysis 216 hardening time were not observed. Therefore, the data from males and females were

217 pooled. In addition, water temperature $\left(27.0 \pm 1.1^{\circ} \mathrm{C}\right)$, salinity $(31.0 \pm 2.1$ ups) and 218 dissolved oxygen concentration $(5.0 \pm 0.52 \mathrm{mg} / \mathrm{L})$ remained largely stable and did not significantly influence any of the dependent variables.

The moulting rate of the animals in pre-ecdysis at the beginning of the experiments ranged from 40 to $95 \%$. Most moulting events occurred during the night, and $50 \%$ of the animals moulted between 52 and 80 hours after the beginning of the experiments. There was a significant effect of moulting on final mortality rate and on 224 survival time after ecdysis (Table 2).

225 Table 2. General results of laboratory experiments to evaluate ecdysis in Callinectes ornatus. 


\begin{tabular}{|c|c|c|c|c|c|c|c|c|c|c|c|c|c|c|}
\hline \multirow{3}{*}{ Exp. } & \multirow{3}{*}{ Group } & \multirow{3}{*}{ Stage } & \multirow{3}{*}{$\mathrm{n}_{1}$} & \multirow{3}{*}{$\begin{array}{l}\text { Weight } \\
\text { Gain } \\
(\%)\end{array}$} & \multicolumn{3}{|c|}{ Ecdysis Performed } & \multirow{2}{*}{\multicolumn{3}{|c|}{$\begin{array}{l}\text { Time to Ecdysis } \\
\text { (h) }\end{array}$}} & \multirow{3}{*}{$\begin{array}{c}\text { Mortality } \\
\text { Rate } \\
(\%)\end{array}$} & \multirow{2}{*}{\multicolumn{3}{|c|}{ Survival Time (h) }} \\
\hline & & & & & \multirow{2}{*}{ Period } & \multirow{2}{*}{$\mathrm{n}_{2}$} & \multirow{2}{*}{$\%$} & & & & & & & \\
\hline & & & & & & & & $25 \%$ & $50 \%$ & $75 \%$ & & $25 \%$ & $50 \%$ & $75 \%$ \\
\hline \multirow[t]{2}{*}{1} & $\mathrm{~A} 1$ & Pre & 46 & 56 & $\begin{array}{l}\text { day } \\
\text { night }\end{array}$ & $\begin{array}{l}14^{a} \\
24^{b}\end{array}$ & 83 & 44.5 & 80 & 124 & $24^{a}$ & 230 & - & - \\
\hline & $A C$ & Inter & 20 & $\mathrm{NA}$ & NA & NA & NA & NA & NA & $\mathrm{NA}$ & $0^{\mathrm{b}}$ & - & - & - \\
\hline \multirow{3}{*}{2} & B1 & Pre & 83 & 69 & $\begin{array}{l}\text { day } \\
\text { night }\end{array}$ & $\begin{array}{l}19^{a} \\
59^{b}\end{array}$ & 94 & 36 & 52 & 78 & $78^{c}$ & 107 & 168 & 212 \\
\hline & B2 & Pre & 40 & 46 & $\begin{array}{l}\text { day } \\
\text { night }\end{array}$ & $\begin{array}{c}3^{a} \\
13^{b}\end{array}$ & 40 & 102 & - & - & $78^{c}$ & 174 & 228 & 413 \\
\hline & $\mathrm{BC}$ & Inter & 53 & NA & $\mathrm{NA}$ & $\mathrm{NA}$ & $\mathrm{NA}$ & $\mathrm{NA}$ & $\mathrm{NA}$ & $\mathrm{NA}$ & $26^{a}$ & 255 & - & - \\
\hline
\end{tabular}

Exp.: experiment number; Pre: pre-ecdysis; Inter: Inter-ecdysis; $n_{1}:$ number of individuals; Weight Gain: increase in post-ecdysis weight (\%); Period: the period in which moult occurred; $n_{2}$ : number and percentage of crabs that performed ecdysis; Time to Ecdysis: time (h) at which 25, 50 and 75\% of the animals had moulted; Mortality rate (\%);Survival Time: time (h) at which 25, 50 and 75\% of the animals survived after ecdysis; NA: Not Applicable. Different letters indicate significant differences $(p<0.05)$ between the groups according to the Kruskal-Wallis test. Experiment 1 (collective treatment with filtration and partial daily water renovation). A1: pre-ecdysis organisms; AC (Control): organisms in inter-ecdysis. Experiment 2 (collective treatment with filtration but no water renewal). B1: pre-ecdysis organisms; B2: tanks containing water previously used for group B1, with organisms in preecdysis; BC (Control): tanks with organisms in inter-ecdysis.

\section{Physical and chemical water parameters}

Table 3. Median and 1st and 3rd quartiles of the water quality parameters in Experiment 1 (collective treatment with filtration and partial daily water renewal).

\begin{tabular}{ccc}
\hline Parameter & Median & $25-75 \%$ \\
\hline $\mathrm{pH}$ & 8.50 & $8.4-8.5$ \\
$\mathrm{~K}+(\mathrm{mg} / \mathrm{L})$ & 380 & $370-390$ \\
$\mathrm{Ca}^{2+}(\mathrm{mg} / \mathrm{L})$ & 350 & $330-430$ \\
$\mathrm{Mg}^{2+}(\mathrm{mg} / \mathrm{L})$ & 589.5 & $573.3-602.6$ \\
$\mathrm{Na}^{+}(\mathrm{mg} / \mathrm{L})$ & 11,000 & $9,900-12,000$ \\
$\mathrm{Cl}(\mathrm{mg} / \mathrm{L})$ & 16,830 & $16,059-17,668$ \\
$\mathrm{TA}(\mathrm{mg} / \mathrm{L})$ & 0.0 & 0.0 \\
$\mathrm{NH}_{3}(\mathrm{mg} / \mathrm{L})$ & 0.0 & 0.0 \\
$\mathrm{NO}_{2}^{-}(\mathrm{mg} / \mathrm{L})$ & 1.30 & $1.29-1.30$ \\
$\mathrm{NO}_{3}(\mathrm{mg} / \mathrm{L})$ & 180 & $170-200$ \\
\hline
\end{tabular}

TA: Total ammonia $\left(\mathrm{NH}_{3}+\mathrm{NH}_{4}{ }^{+}\right)$

In Experiment 2, only potassium and sodium concentrations presented

245 differences between the groups B1 and B2. There was a reduction in $\mathrm{pH}$ and

246 increases in total ammonia and nitrite concentrations in the experimental treatments

247 (pre-ecdysis organisms, B1 and B2) in relation to the control (BA, tanks containing 
248 water only). The variables monitored in the BC tanks (inter-ecdysis organisms)

249 presented intermediate values relative to the other groups (Table 4).

250 Table 4. Median and 1st and 3rd quartiles of the water parameters in Experiment 2

$251 \quad$ (collective treatment with filtration but without water renewal).

\begin{tabular}{|c|c|c|c|c|}
\hline \multirow{4}{*}{ Parameter } & \multicolumn{4}{|c|}{ Groups } \\
\hline & B1 & B2 & BA & $\mathrm{BC}$ \\
\hline & Median & Median & Median & Median \\
\hline & $25-75 \%$ & $25-75 \%$ & $25-75 \%$ & $25-75 \%$ \\
\hline $\mathrm{nH}$ & $6.7^{\mathrm{b}}$ & $6.5^{\mathrm{b}}$ & $8.4^{\mathrm{a}}$ & $7.8^{\mathrm{ab}}$ \\
\hline $\mathrm{pH}$ & $(6.3-7)$ & $(6.2-7)$ & $(8.3-8.4)$ & $(6.8-8.1)$ \\
\hline $\mathrm{K}^{-}(\mathrm{mg} / \mathrm{l})$ & $420.00^{a}$ & $280.00^{\mathrm{b}}$ & $330.00^{\mathrm{ab}}$ & $390.00^{\mathrm{ab}}$ \\
\hline K (mg/L) & $(370-540)$ & $(230-330)$ & $(260-370)$ & $(290-420)$ \\
\hline $\mathrm{Ca}^{2+}(\mathrm{ma} / \mathrm{L})$ & $430.00^{\mathrm{a}}$ & $350.00^{\mathrm{a}}$ & $430.00^{a}$ & $450.00^{\mathrm{a}}$ \\
\hline $\mathrm{Ca}^{2} \quad(\mathrm{mg} / \mathrm{L})$ & $(400-480)$ & $(320-420)$ & $(360-490)$ & $(390-480)$ \\
\hline $\mathrm{Ma}^{2+}(\mathrm{ma} / \mathrm{L})$ & $545.6^{\mathrm{b}}$ & $551.2^{\mathrm{b}}$ & $586.3^{\mathrm{ab}}$ & $592.0^{\mathrm{a}}$ \\
\hline & $(472.3-585.8)$ & $(531.8-622.5)$ & $(573.3-597.4)$ & $(555.2-607.9)$ \\
\hline $\mathrm{Na}^{+}(\mathrm{mg} / \mathrm{l})$ & $12,000^{\mathrm{a}}$ & $7,500^{\mathrm{b}}$ & $11,500^{a b}$ & $12,000^{a b}$ \\
\hline INa (mg/L) & $(10,000-14,000)$ & $(6,500-9,000)$ & $(10,000-13,000)$ & $(10,000-14,000)$ \\
\hline & $18279^{a}$ & $11995^{\mathrm{a}}$ & $15830^{\mathrm{a}}$ & $17602^{\mathrm{a}}$ \\
\hline $\mathrm{CT}^{-}(\mathrm{mg} / \mathrm{L})$ & $(16,507-20,245)$ & $(9,158-15,782)$ & $(14,705-17,473)$ & $(16,122-19,278)$ \\
\hline & $6.8^{\mathrm{b}}$ & $9.5^{\mathrm{b}}$ & $0.0^{\mathrm{a}}$ & $1.1 \mathrm{ab}$ \\
\hline $\mathrm{IA}(\mathrm{mg} / \mathrm{L})$ & $(5.7-10.5)$ & $(7.4-11.91)$ & 0.0 & $(0.0-3.1)$ \\
\hline & $0.02^{\mathrm{b}}$ & $0.02^{\mathrm{b}}$ & $0.00^{a}$ & $0.01 \mathrm{ab}$ \\
\hline $\mathrm{NH}_{3}(\mathrm{mg} / \mathrm{L})$ & $(0.01-0.05)$ & $(0.01-0.05)$ & 0 & $(0-0.08)$ \\
\hline $\mathrm{NO}^{-}-(\mathrm{ma} / \mathrm{l})$ & $4.7^{\mathrm{b}}$ & $5.4^{\mathrm{b}}$ & $1.3^{\mathrm{a}}$ & $5.2^{\mathrm{b}}$ \\
\hline $\mathrm{IVO}_{2} \quad(\mathrm{IIIg} / \mathrm{L})$ & $(2.8-6.5)$ & $(2.15-7.8)$ & $(1.3-1.4)$ & $(4.0-6.1)$ \\
\hline & $230^{\mathrm{a}}$ & $260^{\mathrm{a}}$ & $210^{\mathrm{a}}$ & $230^{\mathrm{a}}$ \\
\hline $\mathrm{NU}_{3}(\mathrm{mg} / \mathrm{L})$ & $(190-310)$ & $(200-340)$ & $(120-260)$ & $(150-280)$ \\
\hline
\end{tabular}

B1: organisms in pre-ecdysis. B2: tanks containing water previously used for group B1 and pre-ecdysis crabs. BA (Control): tanks containing water only. BC (Control): tanks with crabs in inter-ecdysis. Different letters indicate significant differences $(p<0.05)$ between groups according to the Kruskal-Wallis test. TA: Total ammonia $\left(\mathrm{NH}_{3}+\mathrm{NH} 4^{+}\right)$.

256 Influence of the physical and chemical water parameters on the survival and moulting of $C$. ornatus

As expected, crab survival time was influenced by moulting regardless of the rapid exoskeleton hardening and low mortality rates. Therefore, the B1 data were

261 divided into two categories: $\mathrm{M} 1$, animals that moulted within the first $36 \mathrm{~h}$, and $\mathrm{M} 2$, 262 those that moulted after $36 \mathrm{~h}$. The survival of M1 animals was strongly influenced by $263 \mathrm{pH}$ and total ammonia and nitrite concentrations, whereas the survival of the M2 animals was moderately influenced by the same variables. 
Table 5 shows the multiple linear regression results. Crab survival rate was significantly influenced by $\mathrm{pH}$, nitrite and total ammonia in all of the experiments. The remaining parameters had no significant influence $(p<0.05)$ on the crab survival 268 time.

As expected, crab survival time was influenced by moulting regardless of the rapid exoskeleton hardening and low mortality rates. Therefore, the B1 data were 272 divided into two categories: M1, animals that moulted within the first $36 \mathrm{~h}$, and $\mathrm{M} 2$, 273 those that moulted after $36 \mathrm{~h}$. The survival of M1 animals was strongly influenced by $274 \mathrm{pH}$ and total ammonia and nitrite concentrations, whereas the survival of the M2 275 animals was moderately influenced by the same variables.

Table 5. General results of multiple linear regression analysis of the influences of physical and 277 chemical parameters on crab survival time.

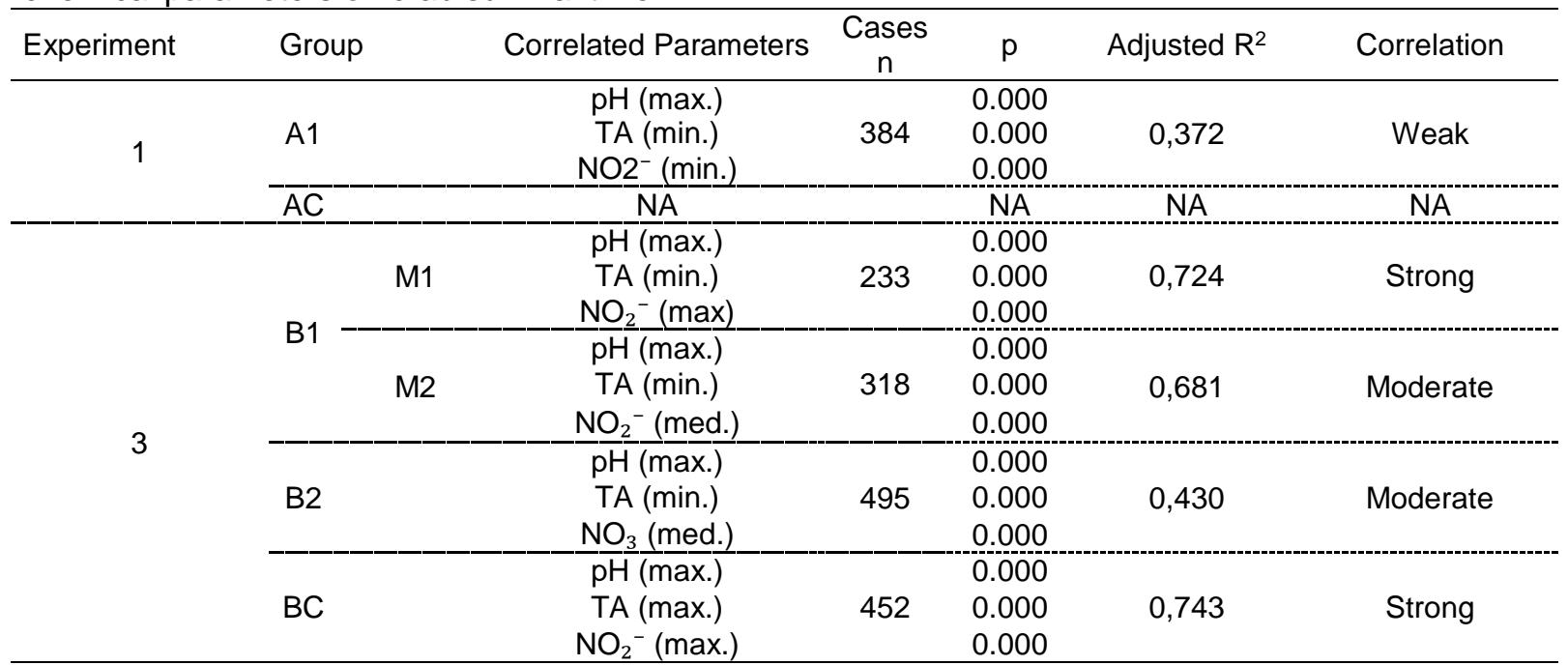

Experiment 1 (collective treatment with filtration and partial daily water renovation). A1: pre-ecdysis crabs; AC (Control): inter-ecdysis crabs. Experiment 2: Collective treatment with filtration but no water renewal. B1: preecdysis crabs; B2: tanks containing water previously used for the B1 group, with pre-ecdysis crabs; BC (Control): tanks with crabs in inter-ecdysis; M1: crabs of B1 Group that performed ecdysis within the first 36 hours; M2: crabs that moulted after 36 hours. NA: Not applicable. TA: Total ammonia $\left(\mathrm{NH}_{3}+\mathrm{NH}^{+}\right)$. 
286 (reached Co 6) or death are presented in Table 6. In Experiment 1, only pH had an

287 influence (weak) on the results. In experiment 2, $\mathrm{pH}$, ammonia and nitrite had

288 moderate influences on the results.

Table 6. General results of multiple linear regression analysis of the influences of physical and chemical parameters on the time until shell hardening or death after ecdysis.

\begin{tabular}{|c|c|c|c|c|c|c|c|}
\hline Experiment & \multicolumn{2}{|c|}{ Group } & Correlated parameters & $\begin{array}{c}\text { Cases } \\
\text { (n) }\end{array}$ & $\mathrm{p}$ & Adjusted $\mathrm{R}^{2}$ & Correlation \\
\hline 1 & A1 & & $\mathrm{pH}(\max )$ & 68 & 0.000 & 0,196 & Weak \\
\hline \multirow{3}{*}{2} & \multirow[b]{2}{*}{ B1 } & $\mathrm{M} 1$ & $\mathrm{pH}(\max )$ & 116 & 0.000 & 0,559 & Moderate \\
\hline & & M2 & $\begin{array}{l}\mathrm{pH} \text { (max.) } \\
\mathrm{AT}(\min .)\end{array}$ & 136 & $\begin{array}{l}0.000 \\
0.000\end{array}$ & 0,410 & Moderate \\
\hline & \multicolumn{2}{|l|}{ B2 } & $\begin{array}{c}\mathrm{AT} \text { (min.) } \\
\mathrm{NO}_{2}^{-} \text {(min.) }\end{array}$ & 203 & $\begin{array}{l}0.000 \\
0.001\end{array}$ & 0,657 & Moderate \\
\hline
\end{tabular}

Experiment 1 (collective treatment with filtration and partial daily water renovation). A1: crabs in pre-ecdysis. Experiment 2 (collective treatment with filtration but no water renewal). B1: crabs in pre-ecdysis; B2: tanks containing water previously used for the B1 group, with crabs also in pre-ecdysis; M1: crabs that moulted within 36 hours; M2: crabs that moulted after 36 hours. TA: Total ammonia $\left(\mathrm{NH}_{3}+\mathrm{NH}^{+}\right)$.

The duration at which the shell was at consistency 2 (i.e., the consistency with

the highest market value) was significantly higher in the $M 2$ animals than in the $M 1$

Co 6 (hard) shells, whereas in the M1 group, more than half of the individuals had shells that reached this consistency. In addition, $68 \%$ of individuals with shells that hardened remain alive. Among those that did not achieve shell hardening, the

Table 7. Duration of Callinectes ornatus at shell consistencies 2 and 3 (Co 2 and Co 3 ) and associated hardening, ecdysis and mortality data in group B1 (organisms initially in pre-ecdysis) of Experiment 2 (collective treatment with filtration but no water renewal). Different letters indicate a significant difference $(p<0.05)$ between the groups (within a column) according to the Kruskal-Wallis or MannWhitney test.

\begin{tabular}{|c|c|c|c|c|c|c|}
\hline Group & $\begin{array}{l}\text { Co 2/3 (h) } \\
\text { (min-max) }\end{array}$ & $n$ & & ning & $\begin{array}{c}\text { Ecdysis } \\
(\mathrm{n}(\%))\end{array}$ & $\begin{array}{c}\text { Dead } \\
(\mathrm{n}(\%))\end{array}$ \\
\hline M1 & $\begin{array}{c}3^{a} \\
(1-18)\end{array}$ & 32 & $\begin{array}{l}\text { Yes } \\
\text { No }\end{array}$ & $\begin{array}{l}(54 \%)^{a} \\
(37 \%)^{a}\end{array}$ & $\begin{array}{l}19(23 \%) \\
13(16 \%)\end{array}$ & $\begin{array}{c}8(42 \%)^{a} \\
11(85 \%)^{b}\end{array}$ \\
\hline M2 & $\begin{array}{c}61^{\mathrm{b}} \\
(3-129)\end{array}$ & 46 & $\begin{array}{l}\text { Yes } \\
\text { No }\end{array}$ & $(100 \%)^{b}$ & $\begin{array}{c}0 \\
46(55 \%)\end{array}$ & $43(93 \%)^{b}$ \\
\hline
\end{tabular}

Individuals who moulted before (M1) or after (M2) 36 hours. 
312 consistency was highly related to the $\mathrm{pH}$ and concentration of total ammonia at the

313 time of moulting. When the levels of the physical and chemical parameters favoured

314 hardening, the time until the organisms reached Co 4 (soft paper) was short

315 (between two and four hours). In contrast, when the $\mathrm{pH}$ was below 7.3 and the total

316 ammonia concentration remained above $6 \mathrm{mg} / \mathrm{L}$, the median time to Co 4 was $60 \mathrm{~h}$.

When water renewal was not performed (Experiment 2), the $\mathrm{pH}$ and total

318 ammonia and nitrite concentrations varied significantly (Figure 2). As a result, there

319 was an increase in the carapace hardening time and a decrease in the number of

320 individuals reaching Co 6 . The crabs of Experiment 1 (A1) and the animals that

321 moulted within the first 36 hours of Experiment 2 (M1) spent significantly less time at

322 Co 2 and Co 3 than did those that moulted after the first 36 hours (M2) in group B1

323 and those in group B2.

Table 8. Water quality parameter measurements and crab survival data registered in the experimental units in which the crabs (Callinectes ornatus) moulted.

\begin{tabular}{|c|c|c|c|c|c|c|c|c|c|c|c|}
\hline \multirow{2}{*}{ Exp. } & \multirow{2}{*}{\multicolumn{2}{|c|}{ Group }} & \multirow{2}{*}{ Co } & \multicolumn{4}{|c|}{$\begin{array}{c}\text { Median } \\
(\text { min-max })\end{array}$} & \multirow{2}{*}{$\begin{array}{c}\text { Mortality } \\
(\%)\end{array}$} & \multicolumn{3}{|c|}{ Survival (h) } \\
\hline & & & & $\mathrm{pH}$ & $\mathrm{TA}(\mathrm{mg} / \mathrm{L})$ & $\mathrm{NO}_{2}^{-}(\mathrm{mg} / \mathrm{L})$ & Time (h) & & $\begin{array}{l}25 \\
\%\end{array}$ & $50 \%$ & $\begin{array}{l}75 \\
\%\end{array}$ \\
\hline \multirow{4}{*}{1} & \multirow{4}{*}{\multicolumn{2}{|c|}{$\begin{array}{l}A \\
1\end{array}$}} & 1 & $\begin{array}{c}8.4^{\mathrm{aA}} \\
(8.4-8.6)\end{array}$ & $\begin{array}{c}0^{\mathrm{aA}} \\
(0-0.3)\end{array}$ & $\begin{array}{c}1.31^{\mathrm{aA}} \\
(1.28-1.50)\end{array}$ & $\begin{array}{c}61^{\mathrm{aAD}} \\
(2-245)\end{array}$ & 15 & \multirow{4}{*}{0} & \multirow{4}{*}{0} & \multirow{4}{*}{0} \\
\hline & & & $2-3$ & $\begin{array}{c}8.4^{\mathrm{a} A}{ }^{-} \\
(8.4-8.5)\end{array}$ & $\begin{array}{l}0^{\mathrm{aA}} \\
0.00\end{array}$ & $\begin{array}{c}1.33^{\mathrm{ab}} \\
(1.29-1.33)\end{array}$ & $\begin{array}{c}4^{\mathrm{bA}} \\
(1-9)\end{array}$ & 2 & & & \\
\hline & & & $4-5$ & $\begin{array}{c}8.5^{\mathrm{abA}} \\
(8.3-8.6)\end{array}$ & $\begin{array}{c}0^{\mathrm{aA}} \\
(0-0.3)\end{array}$ & $\begin{array}{c}1.30^{\mathrm{abA}} \\
(1.28-1.50)\end{array}$ & $\begin{array}{c}26^{\mathrm{cA}} \\
(3-137)\end{array}$ & 4 & & & \\
\hline & & & 6 & $\begin{array}{c}8.5^{\mathrm{bA}} \\
8.5-8.6)\end{array}$ & $\begin{array}{c}0^{\mathrm{aA}} \\
(0-0.3)\end{array}$ & $\begin{array}{c}1.3^{\mathrm{bA}} \\
(1.28-1.50)\end{array}$ & $\begin{array}{c}155^{\mathrm{dA}} \\
(17-209)\end{array}$ & 2 & & & \\
\hline \multirow{9}{*}{2} & \multirow{7}{*}{$\begin{array}{l}B \\
1\end{array}$} & & 1 & $\begin{array}{c}8.4^{\mathrm{a} A} \\
(7.6-8.4)\end{array}$ & $\begin{array}{c}0^{\mathrm{aA}} \\
(0-4.8)\end{array}$ & $\begin{array}{c}1.7^{\mathrm{a}} \\
(1.3-2.72)\end{array}$ & $\begin{array}{l}30^{\mathrm{ac}} \\
(0-36)\end{array}$ & 9 & \multirow{4}{*}{69} & \multirow{4}{*}{150} & \multirow{4}{*}{-} \\
\hline & & & $2-3$ & $\begin{array}{c}7.6^{\mathrm{bA}} \\
(6.7-8.4)\end{array}$ & $\begin{array}{c}4.8^{\mathrm{bA}} \\
(0-9.8)\end{array}$ & $\begin{array}{c}2.7 \mathrm{bA} \\
(1.3-3.22)\end{array}$ & $\begin{array}{c}3^{3 \mathrm{AA}} \\
(1-18)\end{array}$ & 3 & & & \\
\hline & & M1 & $4-5$ & $\begin{array}{c}7.0^{\mathrm{cD}} \\
(5.7-8.3)\end{array}$ & $\begin{array}{c}6.1^{\mathrm{cD}} \\
(1.1-16.5)\end{array}$ & $\begin{array}{c}3.2^{\mathrm{cC}} \\
(1.67-7.85)\end{array}$ & $\begin{array}{c}42^{\mathrm{cC}} \\
(21-234)\end{array}$ & 31 & & & \\
\hline & & & 6 & $\begin{array}{c}6.5^{\mathrm{dB}} \\
(5.5-7.7)\end{array}$ & $\begin{array}{c}8.2^{\mathrm{dB}} \\
(4.5-16.5)\end{array}$ & $\begin{array}{c}5.6^{\mathrm{dB}} \\
(2.27-8.02)\end{array}$ & $\begin{array}{c}183^{\mathrm{CA}} \\
(55-240)\end{array}$ & 20 & & & \\
\hline & & \multirow{3}{*}{ M2 } & 1 & $\begin{array}{c}7.1^{\mathrm{aB}} \\
(5.7-8.4)\end{array}$ & $\begin{array}{c}6.0^{\mathrm{aB}} \\
(0-16.5)\end{array}$ & $\begin{array}{c}2.8^{\mathrm{aC}} \\
(1.3-7.85)\end{array}$ & $\begin{array}{c}60^{\mathrm{aBD}} \\
(36-192)\end{array}$ & 2 & \multirow{3}{*}{66} & \multirow{3}{*}{91} & \multirow{3}{*}{107} \\
\hline & & & $2-3$ & $\begin{array}{c}6.6^{\mathrm{bC}} \\
(5.5-7.5)\end{array}$ & $\begin{array}{c}7.7^{\mathrm{bD}} \\
(3.9-16.5)\end{array}$ & $\begin{array}{c}5.6^{\mathrm{bB}} \\
(2.27-8.02)\end{array}$ & $\begin{array}{c}61^{\mathrm{aC}} \\
(3-129)\end{array}$ & 52 & & & \\
\hline & & & $4-5$ & $\begin{array}{c}6.5^{\mathrm{bc}} \\
(5.5-7.3)\end{array}$ & $\begin{array}{c}9.1^{\mathrm{cC}} \\
(4.5-16.5)\end{array}$ & $\begin{array}{c}5.6^{\mathrm{bD}} \\
(2.27-8.02)\end{array}$ & $\begin{array}{c}45^{\mathrm{aAC}} \\
(3-222)\end{array}$ & 35 & & & \\
\hline & \multirow{2}{*}{\multicolumn{2}{|c|}{$\begin{array}{l}\mathrm{B} \\
2\end{array}$}} & 1 & $\begin{array}{c}6.5^{\mathrm{aC}} \\
(5.3-8.1)\end{array}$ & $\begin{array}{c}9.3^{\mathrm{ac}} \\
(3.3-14.7)\end{array}$ & $\begin{array}{c}5.2^{\mathrm{aD}} \\
(1.35-9.40)\end{array}$ & $\begin{array}{c}177^{\mathrm{aB}} \\
(0-186))\end{array}$ & 38 & \multirow[t]{2}{*}{58} & \multirow[t]{2}{*}{94} & \multirow[t]{2}{*}{144} \\
\hline & & & $2-3$ & $6.5^{\mathrm{aC}}$ & $10.1^{\mathrm{abc}}$ & $6.3^{\mathrm{aBC}}$ & $64^{\mathrm{bBC}}$ & 20 & & & \\
\hline
\end{tabular}


bioRxiv preprint doi: https://doi.org/10.1101/156638; this version posted June 27, 2017. The copyright holder for this preprint (which was not certified by peer review) is the author/funder, who has granted bioRxiv a license to display the preprint in perpetuity. It is made available under aCC-BY-NC-ND 4.0 International license.

\begin{tabular}{cccccc} 
& $(5.8-8.1)$ & $(3.4-14.7)$ & $(1.53-9.40)$ & $(18-126)$ & \\
\hline $4-5$ & $6.5^{\mathrm{aC}}$ & $11.2^{\mathrm{b} C}$ & $4.2^{\mathrm{aBC}}$ & $80^{\mathrm{bABC}}$ & 20 \\
& $(5.8-7.6)$ & $(4.2-14.7)$ & $(1.53-9.40)$ & $(12-180)$ &
\end{tabular}

Exp.: Experiment 1 (collective treatment with filtration and partial daily water renovation), Experiment 2 (collective treatment with filtration but no water renewal). A1 and B1: water not used previously; B2: tanks containing water used previously for the group B1; M1: crabs that moulted within the first 36 hours; M2: crabs that moulted after 36 hours. Co: consistency. TA: total ammonia. Time: Length of stay at a given consistency. Different letters indicate significant differences $(p<0.05)$ according to the Kruskal-Wallis test. Lowercase letters indicate differences in carapace consistency within the same group. Uppercase letters indicate differences in carapace consistency among groups. 


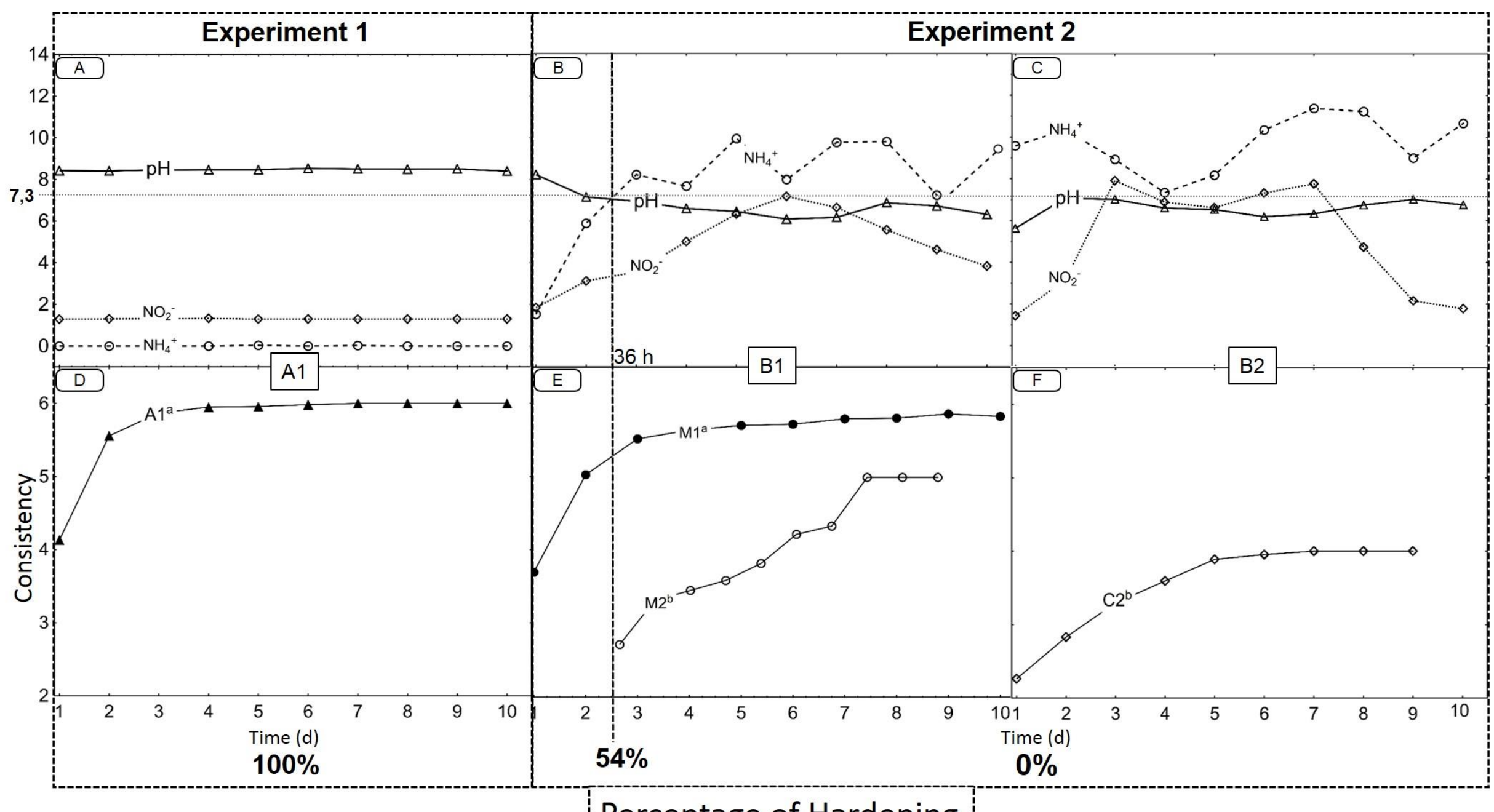

Figure 2. Median $\mathrm{pH}$, total ammonia (mg/L), nitrite $\left(\mathrm{NO}_{2}^{-}\right)(\mathrm{mg} / \mathrm{L})(\mathrm{A}, \mathrm{B}$ and $\mathrm{C})$ and carapace consistency (2 - soft, 3- leather, 4 - soft paper, 5 - hard, paper 6 - hard) over time (in days) (D, E and F). Experiment 1: collective treatment with filtration and partial daily water renewal (66 crabs tested, 46 in pre-ecdysis and 20 in inter-ecdysis stage). Experiment 2: collective treatment with filtration but without water renewal (175 crabs tested, 123 in pre-ecdysis and 52 in inter-ecdysis stage). A1 (46 crabs in pre-ecdysis stage) and B1 (86 crabs in pre-ecdysis stage divided in three replicas): previously unused water and organisms in pre-ecdysis. B2 (40 crabs in 
pre-ecdysis stage): organisms maintained in the reused water of group B1. M1: 32 crabs that moulted within the first 36 hours. M2: 46 crabs that moulted after 36 hours. Different letters indicate significant differences $(p<0.05)$ among groups according to the Kruskal-Wallis test. 


\section{Discussion}

An issue repeatedly debated among those who investigate the shedding and

344 hardening process in crustaceans is the importance of calcium, the main constituent 345 element of the exoskeleton (Greenaway, 1985), in this process (Cameron, 1985;

346 Cameron and Wood, 1985; Clarke and Wheeler, 1922; Freeman and Perry, 1985;

347 Granado e Sá et al., 2010; Greenaway, 1983; Mangum et al., 1985; Middlemiss et 348 al., 2016; Neufeld and Cameron, 1992; Pan et al., 2006; Perry et al., 2001; 349 Robertson, 1960; Welinder, 1974; Wheatly et al., 2001; Wheatly, 1997; Wheatly, 350 1999; Wheatly et al., 2002; Zanotto and Wheatly, 2002). The lack of significant correlations between the concentrations of $\mathrm{Ca}^{2+}$ and $\mathrm{Mg}^{2+}$ in water and either carapace hardening or $C$. ornatus survival does not indicate that calcium is not 353 important in this process. On the contrary, it indicates that certain processes can 354 directly interfere with the physiology of the absorption and immobilisation of $\mathrm{Ca}_{2}{ }^{+}$in 355 the exoskeleton and thereby significantly increase the time that these animals remain soft after moult.

The organisms of Experiment 1 (subjected to daily water renewal) that underwent ecdysis hardened rapidly, achieving paper consistency (Co 4) a median of

$4 \mathrm{~h}$ after moult. This finding is consistent with studies conducted with $C$. sapidus 360 (Cameron and Wood, 1985; Freeman et al., 1987). Similar results were observed 361 among the crabs in Experiment 2 that moulted in water with a pH above 7.6 and a 362 total ammonia concentration below $4.8 \mathrm{mg} / \mathrm{L}$, with Co 4 achieved after a median time 363 of 2 to $3 \mathrm{~h}$. However, among the animals that began moulting in water with a pH 364 below 7.3 and a total ammonia concentration above $6 \mathrm{mg} / \mathrm{L}$, up to $129 \mathrm{~h}$ (median of 365 more than $60 \mathrm{~h}$ ) elapsed before either reaching Co 4 or death. 
To understand this result, it is necessary to understand the chemical

367 processes involved in the calcification of the crab exoskeleton. In a closed system 368 with water recirculation, it is expected that over time there will be a reduction in the 369 concentration of free $\mathrm{Ca}_{2}^{+}$, due mainly to the immobilisation of $\mathrm{Ca}_{2}{ }^{+}$in the form of $370 \mathrm{CaCO}_{3}$ during exoskeleton hardening (Perry et al., 2001). This immobilisation can be 371 represented by the following equation:

$$
\mathrm{Ca}^{2+}+\mathrm{HCO}_{3}{ }^{-} \Leftrightarrow \mathrm{CaCO}_{3}+\mathrm{H}^{+}
$$

With the increased demands for $\mathrm{Ca}_{2}{ }^{+}$and $\mathrm{HCO}_{3}{ }^{-}$, crabs begin to consume 374 both metabolic and external $\mathrm{CO}_{2} . \mathrm{CO}_{2}$ reaches its highest internal concentrations at 375 moulting time (Mangum et al., 1985), increasing the availability of internal $\mathrm{HCO}_{3}$ 376 (Cameron and Wood, 1985). As soon as moulting occurs, the enzyme carbonic 377 anhydrase (CA), present mainly in the epithelium and the gills, is activated (Mangum 378 et al., 1985), accelerating the reaction:

$$
\mathrm{CO}_{2}+\mathrm{H}_{2} \mathrm{O} \Leftrightarrow \mathrm{H}_{2} \mathrm{CO}_{3} \Leftrightarrow \mathrm{H}^{+}+\mathrm{HCO}_{3}^{-}
$$

As explained by Detours et al. (1968) and Zeebe and Wolf-Gladrow (2001), 382 the formed carbonic acid tends to be buffered by the carbonate-bicarbonate system. 383 This process results in an increase in the fraction of $\mathrm{CO}_{3}{ }^{-}$and acidification of the 384 medium (Greenaway, 1974; Mangum et al., 1985; Wheatly, 1997). However, over 385 time, the natural acid neutralisation capacity of the system becomes compromised, 386 and the medium tends to acidify as a result, increasingly compromising the crab's 387 capacity to deposit $\mathrm{CaCO}_{3}$ in its exoskeleton. According to Cameron and Wood 388 (1985), the calcification process can be compromised if the $\mathrm{pH}$ outside the body is 389 less than 0.3 to 0.5 above the internal $\mathrm{pH}$. 
However, in addition to consuming $\mathrm{HCO}_{3}{ }^{-}$post-ecdysis, the organism excretes

$391 \mathrm{H}^{+}$or an equivalent ion such as $\mathrm{NH}_{4}{ }^{+}$(Cameron, 1985; Middlemiss et al., 2016),

392 which is dissociated into $\mathrm{NH}_{3}$ and $\mathrm{H}^{+}$. The rate of $\mathrm{H}^{+} / \mathrm{NH}_{4}{ }^{+}$excretion increases after

393 moulting (Cameron and Wood, 1985) and may increase further during bacterial

394 denitrification (Rijn et al., 2005). Under these conditions, the metabolism of excretion

395 also contributes to the acidification of the medium, further reducing the capacity for

396 calcium mobilisation by the crab, as observed in experiment 2 . There is evidence that

397 water acidification is more critical for the hardening process of marine crustaceans

398 than for that of freshwater crustaceans. Unlike freshwater crustaceans, marine

399 crustaceans have almost no internal reserves of calcium (gastroliths) and depend

400 exclusively on the environment to supply the demand for $\mathrm{Ca}^{2+}$ (Greenaway, 1985;

401 Passano, 1960; Wheatly, 1997).

In a similar manner, acidification might affect the deposition of magnesium in 403 the crustacean exoskeleton. Although magnesium concentrations in water are 404 relatively lower than those of calcium, magnesium also plays an important role in the 405 hardening of the exoskeleton, and it is also obtained through water (Cameron and 406 Wood, 1985; Clarke and Wheeler, 1922; Welinder, 1974) in a process that might be 407 affected by $\mathrm{pH}$ (Tao et al., 2009).

In addition to $\mathrm{Ca}^{2+}$ and $\mathrm{Mg}^{2+}$ concentrations, the concentrations of $\mathrm{Na}^{+}$and $\mathrm{K}^{+}$ 409 were monitored in this study. These two ions directly participate in important 410 enzymatic activities that occur post-ecdysis (Towle and Mangum, 1985). Studies

411 have shown that if the relative proportions of these two ions are altered, ammonia 412 toxicity can occur due to the retention of ammonia by the organism and potentially 413 compromise the anima's survival (Pan et al., 2006; Romano and Zeng, 2011; Zanotto 
414 and Wheatly, 1993). However, were observed no significant effects of these ions in

415 our experiments. It is possible that" the factors described above were much more

416 important in influencing exoskeleton hardening and the probability of survival in $C$.

417 ornatus.

There was also a direct relationship between the time to exoskeleton

419 hardening and the mortality rate. However, the mortality rate was only $25 \%$ among

420 those crabs that moulted after approximately $60 \mathrm{~h}$. Those that did not moult died or

421 remained alive until the end of the experiment. In addition, in all of the groups except

422 those receiving periodic water renewal, there was an increase in mortality in the post-

423 ecdysis phase. In this case, the analyses again indicated the influences of $\mathrm{pH}$ and

424 total ammonia.

It is known that crabs (notably $C$. sapidus, the most studied species of the

426 genus Callinectes) can tolerate a $\mathrm{pH}$ range of 6.5 to 8.5 (Hochheimer, 1988).

427 Nevertheless, in artificial environments, it is recommended that $\mathrm{pH}$ be maintained

428 between 7.0 and 8.0 (Oesterling, 1995). It is also known that there are behavioural

429 and tolerance differences between young and adult animals in relation to $\mathrm{pH}$

430 (Laughlin et al., 1978). In Experiment 2 of the present study, $\mathrm{pH}$ values of 5.5 and 5.3

431 were recorded in groups B1 and B2, respectively. In addition to having a direct effect 432 on the organisms, a reduction of $\mathrm{pH}$ causes an increase in the nitrous acid fraction $433\left(\mathrm{HNO}_{2}\right)$ present in water; $\mathrm{HNO}_{2}$ is toxic to aquatic organisms (Ary and Poirrier, 1989;

434 Lin and Chen, 2003; Russo et al., 1981; Seneriches-Abiera et al., 2007).

The toxicity of ammonia, in turn, is directly proportional to $\mathrm{pH}$ and $\mathrm{NH}_{3}$ 436 concentrations. Romano and Zeng (2007) estimated an LC $\mathrm{C}_{50}$ for juveniles of Scylla 437 serrata of $6.81 \mathrm{mg} / \mathrm{L} \mathrm{NH}_{3}-\mathrm{N}$. Koo et al. (2005) reported that at least $50 \%$ of juveniles 
438 of Orithyia sinica survived for 30 days at approximately $2.33 \mathrm{mg} / \mathrm{L} \mathrm{NH}-\mathrm{N}$. Lakshmi

439 (1984) reported a mortality rate of $20 \%$ in C. sapidus in pre-ecdysis at $1.41 \mathrm{mg} / \mathrm{L}$

$440 \mathrm{NH}_{3}$, which increased to $100 \%$ at $2.31 \mathrm{mg} / \mathrm{L} \mathrm{NH}_{3}$. In our experiments, a $\mathrm{pH}$ reduction

441 was observed over time, which indicated that the $\mathrm{NH}_{3}$ concentrations remained

442 sufficiently low as to rule out any toxic effects of ammonia on C. ornatus.

Regarding nitrite, there is no consensus regarding the concentrations at which

444 this compound is toxic to crabs. Lakshmi (1984) and Ary and Poirrier (1989) reported

445 that the survival of $C$. sapidus was only affected at $\mathrm{NO}_{2}^{-}$concentrations above 10

$446 \mathrm{mg} / \mathrm{L}$. According to those authors, crab mortality reached $100 \%$ only after $96 \mathrm{~h}$ of

447 exposure to concentrations between 50 and $150 \mathrm{mg} / \mathrm{L}$ in water with a $\mathrm{pH}$ close to 8 .

448 In contrast, Manthe et al. (1984) found that the moulting efficiency of $C$. sapidus was

449 affected by nitrite concentrations close to $2 \mathrm{mg} / \mathrm{L}$. In the present study, the nitrite

450 concentration reached $7.6 \mathrm{mg} / \mathrm{L}$. Thus, it is possible that the observed mortality might

451 have been influenced by both $\mathrm{pH}$ and nitrite levels during the experiments and that

452 they had a cumulative effect. Moreover, a long hardening time, which exposed the

453 animals to unfavourable physiological conditions, appears to have significantly

454 increased the risk of death.

455 Conclusion

Moulting in $C$. ornatus exhibited strong relationships with the characteristics of

457 the crab's aquatic medium. The crabs drastically altered the physical and chemical

458 characteristics of the water, mainly through processes related to acidification and

459 ammonification. These alterations, in turn, directly interfered with exoskeleton

460 hardening, causing the exoskeletons of the animals to remain at soft or paper

461 consistency for periods of up to 5 days. Commercially, the establishment of such 
462 periods would allow crabs to be marketed as soft-shell crabs within a time window

463 more than 20 times longer than that typically observed. If the results observed here

464 can be replicated at the commercial scale, large reductions in workload and 465 operational costs could be obtained, increasing the efficiency and viability of large466 scale crab production.

\section{Acknowledgements}

468 We thank GIA (Grupo Integrado de Aquicultura e Estudos Ambientais), Universidade 469 Federal do Paraná and Instituto Federal do Paraná for the opportunity of conducting 470 soft-crabs studies. Thanks to Vitor Rossi, Marcelo F. A. Pinto, Nathiele Cozer and

471 Amanda C. Alburquerque for the collaboration during the experiments. Additionally, 472 we thank the fishermen Zeca Tavares, Túlio and Andréa for the crabs experimental 473 capture. This study is a result of the Master degree thesis of DBH under the post474 graduate initiative "PPG Zootecnia, Universidade Federal do Paraná - UFPR".

\section{Competing interests}

476 No competing interests declared.

\section{$477 \quad$ Funding}

478 This study was supported by the "Conselho Nacional de Desenvolvimento Científico 479 e Tecnológico - CNPq" (process 302609/2013-0) granted to Dr Antonio Ostrensky, 480 and by CNPq financing of the projects associated with this manuscript (processes $481381091 / 2014-7,473959-2013,403705 / 2013-4$ and 468251/2014-6). DBH receives a 482 scholarship from CNPq (DTI, process 381091/2014-7). ACR receives a scholarship 483 from CAPES Pró-Amazônia Program (process 1644571). 


\section{Bibliography}

Ary, R. D. and Poirrier, M. A. (1989). Acute Toxicity of Nitrite to the

Blue Crab (Callinectes sapidus). The Progressive Fish-Culturist 51, 69-72.

Büldt, A. and Karst, U. (1999). Determination of Nitrite in Waters by Microplate Fluorescence Spectroscopy and HPLC with Fluorescence Detection. Analytical Chemistry 71, 3003-3007.

Cameron, J. N. (1985). Post-moult calcification in the blue crab

(Callinectes sapidus): relationships between apparent net $\mathrm{H}+$ excretion,

calcium and bicarbonate. Journal of Experimental Biology 119, 275.

Cameron, J. N. and Wood, C. M. (1985). Apparent H+ Excretion and

CO2 Dynamics Accompanying Carapace Mineralization in the Blue Crab

(Callinectes Sapidus) Following Moulting. Journal of Experimental Biology 114, $181-196$.

Carvalho, F. L. d. and Couto, E. d. C. G. (2011). Environmental 498 variables influencing the Callinectes (Crustacea: Brachyura: Portunidae) species distribution in a tropical estuary-Cachoeira River (Bahia, Brazil). Journal of the Marine Biological Association of the United Kingdom 91, 501 793-800.

Clarke, F. E. (1950). Determination of chloride in water improved 503 colorimetric and titrimetric methods. Analytical Chemistry 22, 553-555.

504 Clarke, F. W. and Wheeler, W. C. (1922). The inorganic 505 constituents of marine invertebrates. Washington: US Government Printing 506 Office. 
Detours, P., Armand, J. and Verriest, G. (1968). Carbon dioxide 508 dissociation curves of water and gas exchange of water-breathers. 509 Respiration Physiology 5, 23-33.

Drach, P. (1939). Mue et cycle d'intermue chez les crustaces

511 decapodes. Ann Inst Oceanogr Monaco 19, 103 - 391.

Drach, P. and Tchernigovtzeff, C. (1967). Sur la méthode de 513 détermination des stades d'intermue et son application générale aux 514 crustacés. Vie milieu 18, 595-609.

515 FAO. (2013). Global Capture Production (FishStat), vol. 2015.

516 http://data.fao.org/dataset-data-filter?entryld=af556541-1c8e-4e98-8510-

517 1b2cafba5935\&tab=data: Food and Agriculture Organization of the United 518 Nations.

Freeman, J. and Perry, H. (1985). The crustacean molt cycle and 520 hormonal regulation: its importance in soft shell blue crab production. 521 Proceedings of the National Symposium on the Soft-Shelled Blue Crab 522 Fishery, $23-30$.

Freeman, J. A., Kilgus, G., Laurendeau, D. and Perry, H. M. 524 (1987). Postmolt and intermolt molt cycle stages of Callinectes sapidus. 525 Aquaculture 61, 201-209.

Gaudé, A. and Anderson, J. A. (2011). Soft shell crab shedding systems, pp. 1-6: Southern Regional Aquaculture Center 
530 freshwater crab Dilocarcinus pagei. Journal of Comparative Physiology $B$ $531 \quad 180,313-321$.

533 the Freshwater Crayfish. Journal of Experimental Biology 61, 35.

Greenaway, P. (1983). Uptake of calcium at the postmoult stage by

535 the marine crabs Callinectes sapidus and Carcinus maenas. Comparative 536 Biochemistry and Physiology Part A: Physiology 75, 181-184.

Greenaway, P. (1985). CALCIUM BALANCE AND MOULTING IN 538 THE CRUSTACEA. Biological Reviews 60, 425-454.

Hochheimer, J. (1988). Water Quality in Soft Crab Shedding: Maryland Sea Grant Extension Program.

542 J. C. (2005). Effects of ammonia and nitrite on survival, growth and 543 moulting in juvenile tiger crab, Orithyia sinica (Linnaeus). Aquaculture 544 Research 36, 79-85.

Lakshmi, G. (1984). The Effect of ammonia accumulation on blue 546 crab shedding success: final report, March, 1983 through December, 1983. $550107,78-86$.

551 Lin, Y.-C. and Chen, J.-C. (2003). Acute toxicity of nitrite on 552 Litopenaeus vannamei (Boone) juveniles at different salinity levels. 553 Aquaculture 224, 193-201. 
555 McMahon, B., Ricci, J., Towle, D. and Wheatly, M. (1985). Physiology of 556 the blue crab Callinectes sapidus Rathbun during a molt. In National 557 Symposium on the Soft-Shelled Blue Crab Fishery, pp. 1-12.

Manthe, D. P., Malone, R. F. and Kumar, S. (1984). Limiting factors associated with nitrification in closed blue crab shedding systems. Aquacultural Engineering 3, 119-140.

Melo-Filho, G. A. S. d. (1996). Manual de identificacao dos brachyura (caranguejos e siris) do litoral brasileiro. São Paulo: Plêiade/FAPESP.

565 of seawater alkalinity on calcium and acid-base regulation in juvenile 566 European lobster (Homarus gammarus) during a moult cycle. Comparative 567 Biochemistry and Physiology Part A: Molecular \& Integrative Physiology 568 193, 22-28.

Mukaka, M. M. (2012). Statistics Corner: A guide to appropriate use 570 of Correlation coefficient in medical research. Malawi Medical Journal 24, 5713.

Neufeld, D. S. and Cameron, J. N. (1992). Postmoult Uptake of 573 Calcium by the Blue Crab (Callinectes Sapidus) in Water of low Salinity. 574 Journal of Experimental Biology 171, 283. 
577 Callinectes sapidus Rathbun. Journal of Experimental Zoology 110, 113578152. $583 \mathrm{Mg} 2+/ \mathrm{Ca} 2+$ ratios in saline groundwaters on $\mathrm{Na}+-\mathrm{K}+-\mathrm{ATPase}$ activity, 584 survival and growth of Marsupenaeus japonicus postlarvae. Aquaculture 585 261, 1396-1402.

Passano, L. (1960). Molting and its control. The Physiology of 587 Crustacea 1, 473-536.

Perry, H., Graham, D., Trigg, C. and Crochet, G. (2010). 589 Expansion of the Soft Crab Fishery in Mississippi Using Cultured Blue 590 Crabs, vol. 63, pp. 5: Gulf and Caribbean Fisheries Institute, c/o Harbor 591 Branch Oceanographic Institution, Inc. Fort Pierce FL 34946 United 592 States.

594 Henry, R. (2001). Calcium concentration in seawater and exoskeletal 595 calcification in the blue crab, Callinectes sapidus. Aquaculture 198, 197596208.

Rijn, J. v., Tal, Y. and Schreier, H. J. (2005). Denitrification in 598 recirculating systems: Theory and applications. Aquaculture Engineering $59934,12$. 
Robertson, J. D. (1960). Ionic regulation in the crab Carcinus 601 maenas (L.) in relation to the moulting cycle. Comparative Biochemistry 602 and Physiology 1, 183-212.

603

Romano, N. and Zeng, C. (2007). Acute toxicity of ammonia and its 604 effects on the haemolymph osmolality, ammonia-N, $\mathrm{pH}$ and ionic 605 composition of early juvenile mud crabs, Scylla serrata (Forskål). 606 Comparative Biochemistry and Physiology Part A: Molecular \& Integrative 607 Physiology 148, 278-285.

608

Romano, N. and Zeng, C. (2011). Importance of balanced $\mathrm{Na}+\mathrm{K}+$ 609 ratios for blue swimmer crabs, Portunus pelagicus, to cope with elevated 610 ammonia- $\mathrm{N}$ and differences between in vitro and in vivo gill $\mathrm{Na}+\mathrm{K}_{+-}$ 611 ATPase responses. Aquaculture 318, 154-161.

Russo, R. C., Thurston, R. V. and Emerson, K. (1981). Acute 613 Toxicity of Nitrite to Rainbow Trout (Salmo gairdneri): Effects of $\mathrm{pH}$, Nitrite 614 Species, and Anion Species. Canadian Journal of Fisheries and Aquatic 615 Sciences 38, 387-393. 617 (2007). Acute toxicity of nitrite to mud crab Scylla serrata (Forsskål) 618 larvae. Aquaculture Research 38, 1495-1499.

619 Tao, J., Zhou, D., Zhang, Z., Xu, X. and Tang, R. (2009). 620 Magnesium-aspartate-based crystallization switch inspired from shell molt 621 of crustacean. Proceedings of the National Academy of Sciences 106, $622 \quad 22096-22101$. 
Towle, D. W. and Mangum, C. P. (1985). Ionic regulation and

624 transport ATPase activities during the molt cycle in the blue crab 625 Callinectes sapidus. Journal of crustacean biology 5, 216-222.

Wehrtmann, I. S. and Mena-Castañeda, D. (2003). molt sign 627 description of the pacific blue crab Callinectes arcuatus Ordway 1863 628 (Decapoda, Portunidae). Nauplius 11, 135-139.

Welinder, B. S. (1974). The crustacean cuticle - I. Studies on the 630 composition of the cuticle. Comparative Biochemistry and Physiology Part A: Physiology 47, 779-787.

Wheatly, M., Zhang, Z., Weil, J., Rogers, J. and Stiner, L. (2001).

633 Novel subcellular and molecular tools to study $\mathrm{Ca}(2+)$ transport 634 mechanisms during the elusive moulting stages of crustaceans: flow 635 cytometry and polyclonal antibodies. Journal of Experimental Biology 204, 636 959-966.

Wheatly, M. G. (1997). Crustacean Models for Studying Calcium 638 Transport: The Journey from Whole Organisms to Molecular Mechanisms. 639 Journal of the Marine Biological Association of the United Kingdom 77, $640 \quad 107-125$.

Wheatly, M. G. (1999). Calcium homeostasis in crustacea: The 642 evolving role of branchial, renal, digestive and hypodermal epithelia. 643 Journal of Experimental Zoology 283, 620-640. 
646 Biochemistry and Physiology Part B: Biochemistry and Molecular Biology 647 132, 163-178.

648 Zanotto, F. P. and Wheatly, M. G. (1993). The Effect of Ambient pH 649 on Electrolyte Regulation During the Postmoult Period in Freshwater 650 Crayfish Procambarus clarkii. Journal of Experimental Biology 178, 1. Zanotto, F. P. and Wheatly, M. G. (2002). Calcium balance in 652 crustaceans: nutritional aspects of physiological regulation. Comparative 653 Biochemistry and Physiology Part A: Molecular \& Integrative Physiology $654133,645-660$. Zeebe, R. E. and Wolf-Gladrow, D. A. (2001). CO2 in seawater: 656 equilibrium, kinetics, isotopes: Gulf Professional Publishing. 